\title{
Interactions between Climate Change and Complex Topography Drive Observed Streamflow Changes in the Colorado River Basin $\mathscr{0}$
}

\author{
KuRT C. SOLANDER AND KATRINA E. BENNETT \\ Los Alamos National Laboratory, Los Alamos, New Mexico \\ SEAN W. FLEMING \\ White Rabbit R\&D LLC, and Oregon State University, Corvallis, Oregon, and University of British Columbia, \\ Vancouver, British Columbia, Canada, and Los Alamos National Laboratory, Los Alamos, New Mexico \\ DAVID S. GUTZLER \\ Department of Earth and Planetary Sciences, University of New Mexico, Albuquerque, New Mexico \\ EMILY M. HOPKINS AND RICHARD S. MIDDLETON \\ Los Alamos National Laboratory, Los Alamos, New Mexico
}

(Manuscript received 19 January 2018, in final form 28 August 2018)

\begin{abstract}
The Colorado River basin (CRB) is one of the most important watersheds for energy, water, and food security in the United States. CRB water supports $15 \%$ of U.S. food production, more than $50 \mathrm{GW}$ of electricity capacity, and one of the fastest growing populations in the United States. Energy-water-food nexus impacts from climate change are projected to increase in the CRB. These include a higher incidence of extreme events, widespread snow-to-rain regime shifts, and a higher frequency and magnitude of climate-driven disturbances. Here, we empirically show how the historical annual streamflow maximum and hydrograph centroid timing relate to temperature, precipitation, and snow. In addition, we show how these hydroclimatic relationships vary with elevation and how the elevation dependence has changed over this historical observational record. We find temperature and precipitation have a relatively weak relation $(|r|<0.3)$ to interannual variations in streamflow timing and extremes at low elevations $(<1500 \mathrm{~m})$, but a relatively strong relation $(|r|>0.5)$ at high elevations $(>2300 \mathrm{~m})$ where more snow occurs in the CRB. The threshold elevation where this relationship is strongest $(|r|>0.5)$ is moving uphill at a rate of up to $4.8 \mathrm{~m} \mathrm{yr}^{-1}(p=0.11)$ and $6.1 \mathrm{~m} \mathrm{yr}^{-1}(p=0.01)$ for temperature and precipitation, respectively. Based on these findings, we hypothesize where warming and precipitation-related streamflow changes are likely to be most severe using a watershed-scale vulnerability map to prioritize areas for further research and to inform energy, water, and food resource management in the CRB.
\end{abstract}

\section{Introduction}

Streamflow is vitally important to energy, water, and food resources (Das et al. 2011). Over half of all global potable water supplies are sourced from streamflow (Barnett et al. 2005). Moreover, streamflow is used to generate a substantial amount of power in places like

Supplemental information related to this paper is available at the Journals Online website: https://doi.org/10.1175/JHMD-18-0012.s1.

Corresponding author: Kurt C. Solander, ksolander@lanl.gov the western United States where renewable energy accounts for over half of the total energy supplies (Bartos and Chester 2015). Nowhere is the threat of change to these resources from a warming climate more profound than in the U.S. Southwest, where the region's hot and dry climate coupled with a large and growing population leads to an increased reliance on what limited streamflow is available, resulting in the widespread overexploitation of this resource (Solander et al. 2017a).

Examples of the overexploitation of water in the U.S. Southwest include high levels of annual water scarcity and the degree of streamflow regulation that causes 
total reservoir storage volume to exceed the annual natural flow of rivers by a factor of 2.5 in the Colorado River basin (CRB; Nilsson et al. 2005; Sabo et al. 2010). The extent of regulation is so great for CRB water supplies-which are shared among seven U.S. states and Mexico- that the Colorado River no longer reaches its natural terminus in the Gulf of California, except under mandate to mimic historical conditions for environmental benefits (Witze 2014). The high rate of population growth coupled with projected climate-induced changes to the hydrology of the CRB means that the management of this resource will only continue to intensify (MacDonald 2010). Thus, the degree of necessary improvements to the management system are a function of both the expected increase in demand stemming from the increase in population, as well as shifts in the supply resulting from future warming. Here, we report insights into changes in water supplies using statistical models to investigate the changing role of climate in historical CRB streamflow.

Climate variables most relevant for changes in streamflow include both temperature and either frozen or liquid precipitation. Although precipitation was found to explain $66 \%$ of the variability in 1906-2012 Colorado River streamflow, temperature was found to also be important for modulating precipitation impacts on streamflow during drought years or during anomalously high- or low-flow years (Woodhouse et al. 2016; Lehner et al. 2017a). Similarly, by lowering the runoff efficiency, temperature was found to decrease mean annual flow by $7 \%$ in the Colorado River basin over the past three decades (McCabe et al. 2017). A 445-yr streamflow record reconstructed from tree rings in the adjacent Rio Grande basin was used to determine a comparable finding that although streamflow tracks precipitation more closely than temperature, the probability of a year with a low runoff ratio increases by a factor of 3 under high temperatures (Lehner et al. 2017b). Temperature impacts streamflow through its influence on both evapotranspiration (ET) and snowmelt (Ficklin et al. 2013; Vano et al. 2015; Foster et al. 2016). For example, increases in temperature were shown to be responsible for one-third of the $19 \%$ decline in mean annual flow for the Colorado River over the 2000-14 drought (Udall and Overpeck 2017). Snow has a strong influence on streamflow within the CRB at elevations above 2300-2500 m (Clow 2010; Kampf and Lefsky 2016). Changes in climate are also expected to shift the seasonality of rain-snow transition elevations (Knowles et al. 2006; McCabe et al. 2007; Feng and $\mathrm{Hu}$ 2007; Barnett et al. 2008; Kumar et al. 2012; Klos et al. 2014; Berghuijs et al. 2014), which will further transform streamflow.
Numerous observational and modeling studies have investigated drivers of past and future changes in both CRB streamflow and snowpack, which accounts for over $70 \%$ of the flow in the Colorado River (Skiles et al. 2015). Higher temperatures during the cool season (October-March; Hamlet et al. 2007; Luce et al. 2014; Mankin and Diffenbaugh 2015), winter (January-March; Mote 2006; Miller and Piechota 2008; Pederson et al. 2013), and spring (April-June; McCabe and Clark 2005; Clow 2010; Fritze et al. 2011; Kapnick and Hall 2012) have all been linked to declines in spring snowpack, earlier snowmelt onset, and shifts toward earlier streamflow centroid timing (CT). Increases in atmospheric dust deposition also accelerate snowmelt (Painter et al. 2010). In addition, CT shifts were linked to several large climate regime shifts including the Pacific decadal oscillation (PDO) and El Niño-Southern Oscillation (ENSO; Regonda et al. 2005; McCabe and Clark 2005). More recently, the Atlantic multidecadal oscillation (AMO) was found to be most strongly correlated to temperature in the upper CRB, which, in turn, was found to be associated with a low-frequency mode of Colorado River flow that modulates runoff efficiency (e.g., proportion of precipitation that gets incorporated into runoff). On the other hand, precipitation within this region was most strongly correlated to sea surface temperatures in the equatorial and northern Pacific, which, in turn, were related to a higher-frequency mode of Colorado River flow (Nowak et al. 2012). Global climate model (GCM) simulations also show human-induced temperature increases are responsible for up to $60 \%$ of simulated future changes in CT and the closely related snowpack-to-precipitation ratio (Barnett et al. 2008).

Annual streamflow within the CRB is projected to decrease by up to $11 \%$ by 2100 due to climate change, with additional decreases in densely forested regions of up to $10 \%$ from climate-driven vegetation disturbances (Bennett et al. 2018). Median upper-CRB spring and summer streamflow is projected to decrease by $36 \%$ and $46 \%$, respectively, due to higher ET accompanied by timing shifts and declines in snowmelt by the end of the twenty-first century (Ficklin et al. 2013). Transformations in snow and snowmelt patterns were identified as the likely cause of major shifts in the seasonality of extreme streamflow based on temporal and spatial patterns of change (Solander et al. 2017b).

Although these model- and observation-based studies of streamflow changes are useful for describing the magnitude of temporal streamflow shifts and where they occur spatially, far less work has been completed on quantifying the elevation-dependent relationships between streamflow changes and different climate 
TABLE 1. Summary of spatial statistics for different station groups and analytical metrics.

\begin{tabular}{lccccc}
\hline \hline Analysis $^{\mathrm{a}}$ & Record length & No. of stations ${ }^{\mathrm{b}}$ & ${\text { Latitude range }\left({ }^{\circ}\right)}$ & Longitude range $\left(^{\circ}\right)$ & Elevation range $(\mathrm{m})$ \\
\hline $\mathrm{CT}$ & $1985-2014$ & $n=41$ & $31.36-43.03$ & -115.30 to -105.91 & $428-3179$ \\
$Q_{\max }$ & $1985-2014$ & $n=40$ & $31.36-43.03$ & -115.30 to -105.91 & $536-3179$ \\
$\mathrm{CT}$ & $1975-2014$ & $n=42$ & $31.36-43.03$ & -115.30 to -105.91 & $536-3179$ \\
$Q_{\max }$ & $1975-2014$ & $n=39$ & $31.36-43.03$ & -115.30 to -105.91 & $536-3179$ \\
$\mathrm{CT}$ & $1965-2014$ & $n=20$ & $31.36-43.03$ & -115.30 to -105.97 & $536-2850$ \\
$Q_{\max }$ & $1965-2014$ & $n=20$ & $31.36-43.03$ & -115.30 to -105.97 & $536-2850$ \\
CT & $1955-2014$ & $n=8$ & $31.36-43.03$ & -110.81 to -106.27 & $829-2789$ \\
$Q_{\max }$ & $1955-2014$ & $n=8$ & $31.36-43.03$ & -110.81 to -106.27 & $829-2789$ \\
\hline
\end{tabular}

${ }^{\text {a }}$ There are fewer stations in $Q_{\max }$ analysis because more restrictive data filtering methods were used.

${ }^{\mathrm{b}}$ Stations included in longer record length analysis were also used in shorter record length analysis.

variables. Historical relationships among precipitation, temperature, and streamflow (Vano et al. 2014) as well as future estimates of these variables with respect to elevation (Gao et al. 2009) within the CRB have both been examined using physically based dynamical models. Here, we link these and other previous lines of investigation by empirically demonstrating how historically observed precipitation, temperature, and snowpack influence streamflow extremes and timing, how these relationships vary with elevation, and how this elevation dependence has changed under latetwentieth- to early-twenty-first-century climate changes. The innovations of our work include an explicit quantification of these relationships both across the landscape and with elevation. Moreover, we base our analysis on observational and observation-based datasets to establish a historical baseline using direct empirical evidence.

Our approach additionally allows us to use these observations of temperature, precipitation, snow, and streamflow data as a proxy for examining historical changes in precipitation phase, for which direct longterm observations are limited. Tracking elevationdependent hydroclimatic relationships over about half a century provides insights into how climate change has altered basin-scale water input-output relationships. This empirical baseline information can be used as a benchmark for ensuring that hydroclimatic processes are adequately represented in process simulation models and to better understand the context for future projected changes in hydrology. Such efforts will improve the understanding and prediction of snowmeltrelated process impacts on streamflow. This is vital given that runoff forecasting errors can reach up to $80 \%$ in the western United States during the snowmelt season (Bryant et al. 2013).

The paper describes the development of statistical models to relate observed annual CT and annual maximum streamflow $Q_{\max }$ to local temperature and precipitation and explore how these relationships vary with elevation. We then evaluate how the elevation dependence of these relationships has shifted through time. Our work culminates in the generation of a map to show the watersheds most vulnerable to future streamflow change. The map is designed to support prioritization of areas for future research and to inform long-term energy, water, and food resource management and planning in the CRB.

\section{Methods}

We used the $Q_{\max }$ and CT annual data of Solander et al. (2017b) for this analysis, which were derived using observations from U.S. Geological Survey GAGES-II streamflow gauges (Falcone et al. 2010). The $Q_{\max }$ and CT are annual streamflow extremes and timing variables based on observational time series of daily flows. Specifically, $Q_{\max }$ is the annual maximum daily mean streamflow, and $\mathrm{CT}$ is the centroid of the annual hydrograph - that is, the sequential day of the calendar year on which half of that year's total flow volume has passed. Station data were generated using only natural streamflow records with minimum 30-yr record length to increase the chances that observed transformations in streamflow were derived from changes in climate, rather than those pertaining to land use or water management. Data were grouped according to record lengths of 30, 40, 50, and 60 years (Table 1 ) to determine if similar results could be found over different periods (Fig. 1), thereby reducing the influence of shorter-term episodic climate events such as ENSO or PDO on our overall results (Solander et al. 2017b). Stations found in the longer record groups were also used in the shorter record groups to maximize the number of stations used in the analysis. Our intent was that the results of each station group be considered as a stand-alone analysis to be compared to the results of the other station groups. Additional information on the streamflow gauge records used in this study can be found in Solander et al. (2017b). 


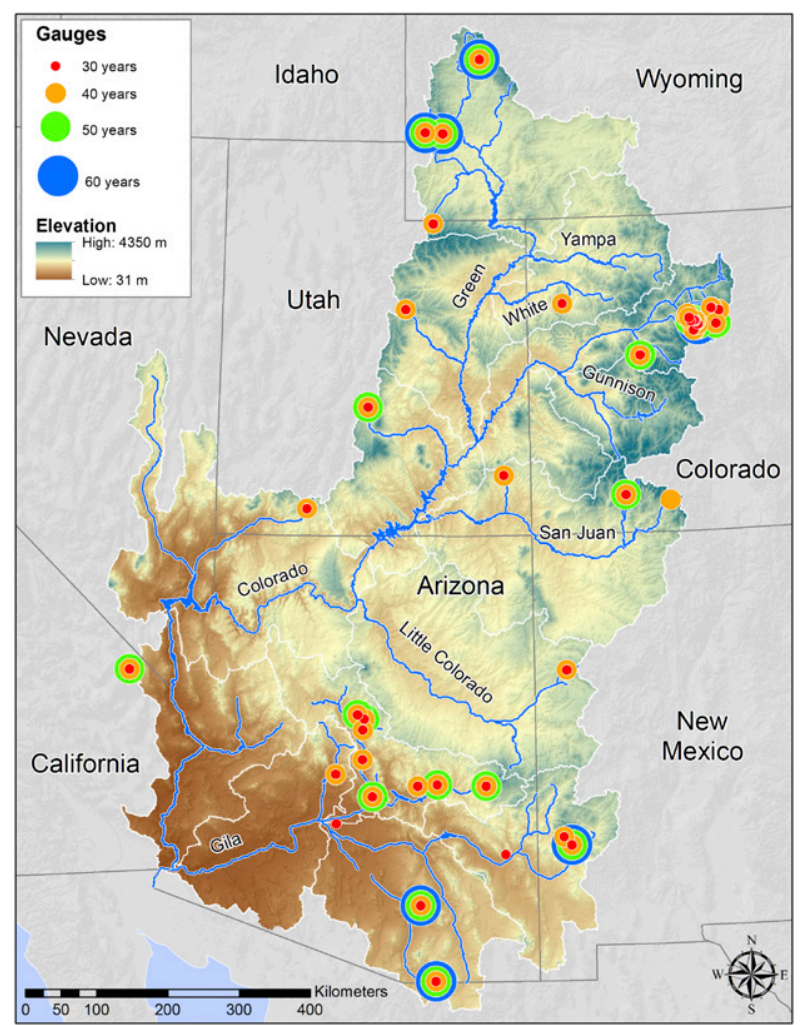

FIG. 1. Study area of the CRB showing the streamflow gauges that were used in the analysis with corresponding record length of 30 years (1985-2014), 40 years (1975-2014), 50 years (1965-2014), and 60 years $(1955-2014)$.

Monthly temperature and precipitation data used to correlate with the annual streamflow metrics were obtained from the Parameter-Elevation Regressions on Independent Slopes Model (PRISM) 4-km resolution monthly grid cell that encompassed the location of the streamflow gauge of interest (Daly et al. 2008). Only headwater streamflow gauges were used in the analysis (see Fig. 1). To demonstrate this, we conducted a geospatial analysis on the proportion of a watershed upstream from a given gauge relative to the 4-digit hydrologic unit code 4 (HUC-4) watershed that encompassed the gauge (see online supplemental material). The maximum watershed area upstream from a given streamflow gauge was $4804 \mathrm{~km}^{2}$, representing only $12.2 \%$ of associated HUC- 4 watershed. For the other gauges, the upstream watershed was less than $800 \mathrm{~km}^{2}$, accounting for no more than $2.1 \%$ of the HUC-4 watershed.

Snow is described using daily grid-based Daymet (version 3) snow water equivalent (SWE) data at 1-km resolution that were interpolated and extrapolated from selected meteorological stations (Thornton et al. 2017). Daymet climate data are continuous with a record extending to 1980 . However, only 30 years of SWE were used, beginning in 1985 , so that SWE could eventually be correlated with the 30-yr mean annual $Q_{\max }$ and CT. Daily SWE was aggregated to monthly SWE. Similar to the temperature and precipitation data from PRISM, we used the Daymet grid cell that encompassed the streamflow gauge station employed in the correlation analysis described below.

The use of collocated gridded climate and streamflow gauge data was important for avoiding bias in correlations caused by incorporating data from more distant climate grid cells that would increase the likelihood of comparing records driven by dissimilar weather patterns (Luce et al. 2014). Because correlation is used here as a measure of association, for which bias does not matter, and because climate correlation length scales are large compared to our headwater basin sizes, basing the analysis on climate data from the single PRISM grid cell encompassing the stream gauge was verified in two ways. First, we correlated the PRISM temperature and precipitation data from the grid cell collocated with the streamflow gauge against aggregated mean PRISM temperature and precipitation data for the basin area upstream of that gauge. This was done for the five largest basins, which represent a worst-case scenario for the basinwide representativeness of a single PRISM grid cell $\left(517-4800 \mathrm{~km}^{2}\right.$, equivalent to approximately $32-300$ PRISM grid cells). Correlation coefficients between collocated and aggregated PRISM temperature and precipitation were $>0.99$ and $0.93-0.98$, respectively. Second, we recalculated the climate-streamflow correlation analyses described in the following paragraph using the mean aggregated temperature and precipitation from PRISM cells located upstream of the streamflow gauge. This calculation was applied in the basin having the largest drainage area upstream of a streamflow gauge with a minimum elevation of $2000 \mathrm{~m}$, where associations between snow-related streamflow and climate measures are present; this again represents a worst-case scenario for the basinwide representativeness of single-grid-cell PRISM values. For CT, the correlation comparisons showed the amount of streamflow variability explained by temperature and precipitation for the two estimates was within $1.5 \%$ (mean $r=-0.84$ ) and $7.5 \%$ (mean $r=0.65$ ), respectively, of each other. For $Q_{\max }$, the correlations between the amount of variability in streamflow explained by temperature and precipitation for the two estimates was within $3.3 \%$ (mean $r=-0.64$ ) and 8.1\% (mean $r=0.50$ ), respectively. We also note that our use of local grid cell temperature and precipitation data in the regression follows other studies that regressed collocated climate 
data with streamflow (Cayan et al. 1993; Groisman et al. 2001; Hodgkins et al. 2012).

We correlated monthly temperature, precipitation, and SWE with annual $Q_{\max }$ and CT data to evaluate how local climate influences streamflow extremes and timing. Our approach builds on prior work that statistically relates temperature and precipitation to snowpack variability (Morán-Tejeda et al. 2013; Sospedra-Alfonso et al. 2015; Scalzitti et al. 2016). We employed a sensitivity analysis to determine which month or consecutive months of temperature, precipitation, and snow were most strongly correlated to the annual $Q_{\max }$ and CT data and were therefore most appropriate to use for this analysis (Sospedra-Alfonso et al. 2015; Scalzitti et al. 2016). Because the sensitivity analysis showed consistently high correlations with little difference in results, as long as some combination of March-June values of temperature, precipitation, and snow were used, we chose the mean over one month or consecutive months within this group of months for the correlation analysis against annual $Q_{\max }$ and CT.

We note that streamflow patterns throughout the Colorado River basin are typical of other mountainous regions whereby flow builds throughout the snowmelt season, culminating in a maximum that typically falls between March and June (Dunne and Leopold 1978). As such, the use of monthly climate variables to determine the relationship with streamflow is justified. Had this study been conducted in a different region where the timing of peak streamflow is more likely to be influenced by the precipitation from a single storm event, the use of daily climate variables to determine the hydroclimatic relationships would have been more appropriate.

Following the sensitivity experiments, resulting correlations that depict relationships between interannual climatic variability and interannual hydrologic variability were plotted against elevation. Linear model trend lines were fit to these data. These statistics were calculated for stations above $1300 \mathrm{~m}$, given that the correlation of annual $Q_{\max }$ and CT with local precipitation, temperature, and snowpack approached zero below this elevation. More importantly, as we describe below, snow is the likely driver of changes in correlation, and areas below this elevation in the CRB receive virtually no snow. Note that we also fit linear and nonlinear regression curves through the correlation points at all elevations. Results were similar in all cases, so in the interest of parsimony, results for the simpler linear regression methods are discussed here, with regression lines fit only to points at elevations above $1300 \mathrm{~m}$.

To determine how the dependency of streamflow on temperature, precipitation, and snow has shifted over time, we also examined changes in the mean elevation where temperature, precipitation, and snow explain $25 \%$ of the variability in annual $Q_{\max }$ and CT. A value of $R^{2}=0.25(R=0.5)$ was chosen as a convenient threshold for tracking relationships between longterm hydroclimatic dynamics and complex watershed topography. First, the streamflow gauge elevations were linearly related to the climate-streamflow correlation coefficients discussed above. Six equations were estimated using regression, one for each climate variable-streamflow variable pair. For instance, if $z_{\text {gauge }}$ denotes the gauge elevation and $R_{\text {temp-CT }}$ denotes the correlation coefficient between annual spring temperature and the annual hydrograph centroid timing at that gauge, then

$$
z_{\text {gauge }}=\beta_{0}+\beta_{1} R_{\text {temp-CT }},
$$

where $\beta_{0}$ and $\beta_{1}$ are regression coefficients. The elevation at which temperature accounts for $25 \%$ of the variance in annual CT can then be estimated by setting $R_{\text {temp-CT }}$ to 0.5 . This equation is applied using a $10-\mathrm{yr}$ moving window to the correlation coefficients to generate a time series of annual estimated elevations at which $25 \%$ of the variability in the annual CT is explained. Regression coefficients were recalculated with each application of Eq. (1). We used the Mann-Kendall test to determine whether a significant trend in the elevation estimates was present. The Theil-Sen slope estimator was used to obtain the corresponding linear trend rate. The process was then repeated for the five remaining climate variable-streamflow variables pairs. A value of $R=0.5$ is an arbitrary but reasonable threshold choice that has been used previously for compact identification of hydroclimatic linkages (Tsonis et al. 2006). Given that the trend analysis was conducted for all climate variable-streamflow variable pairs, this analysis effectively determines the mean change in elevation at which a certain climate variable is related to either $Q_{\max }$ or CT over the entire Colorado River basin.

\section{Results}

The correlations between annual $Q_{\max }$ versus AprilMay temperature and April precipitation with respect to streamflow gauge elevation for the periods 1955-2014, 1965-2014, 1975-2014, and 1985-2014 are shown in Fig. 2. Red circles represent the correlation between gauged annual $Q_{\max }$ and the mean April-May temperature from PRISM, whereas blue circles represent the correlation between gauged annual $Q_{\max }$ and the mean April PRISM precipitation. Trend lines show the linear fit between the two sets of correlations with respect to 
a. $1985-2014$
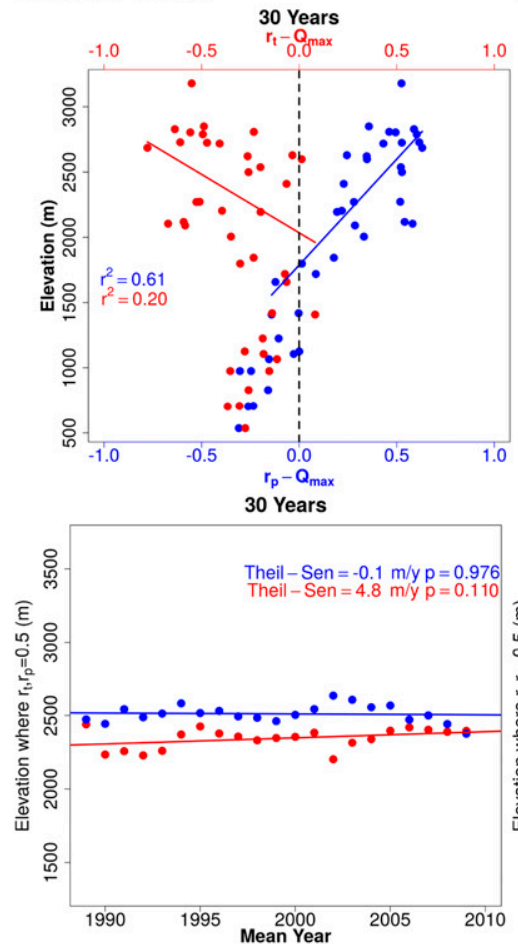

d. 1955-2014

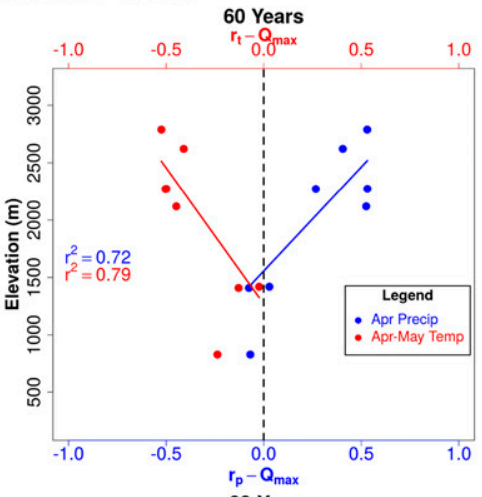

60 Years

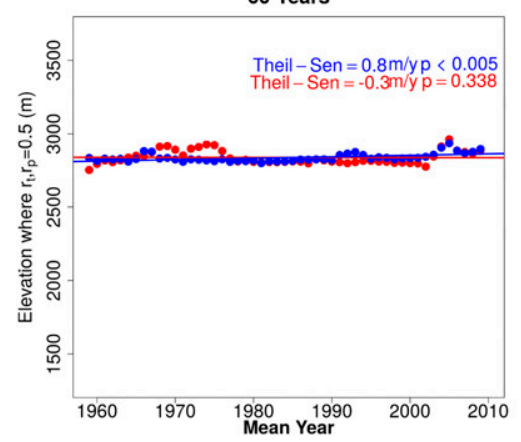

b. $1975-2014$

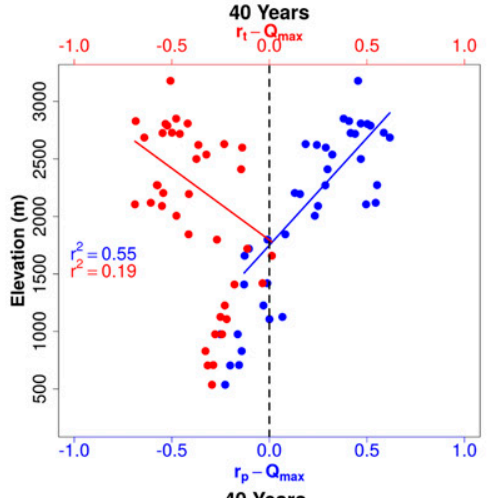

c. 1965-2014

50 Years
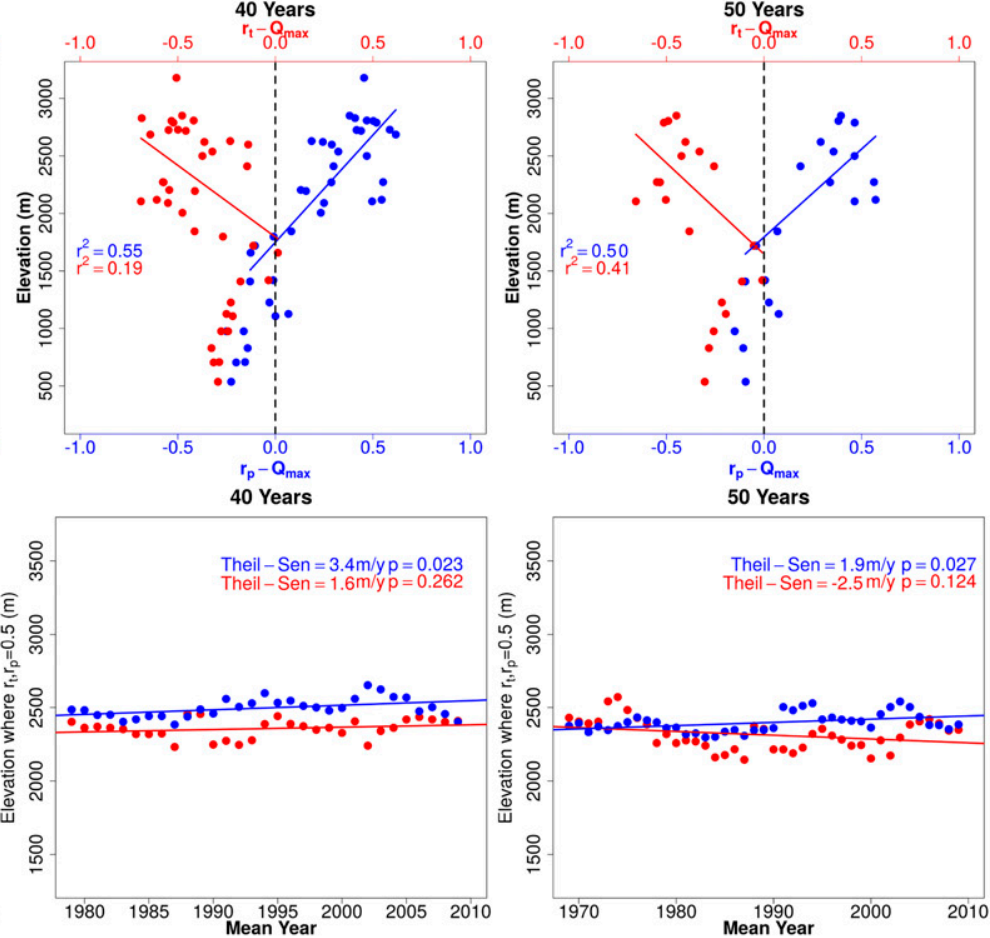

FIG. 2. (top) Pearson correlation coefficients between annual $Q_{\max }$ vs April precipitation (blue circles with blue linear fit) and vs April-May temperature (red circles with red linear fit) plotted against elevation for (a)-(d) each period. Linear fits were conducted only for stations above $1300 \mathrm{~m}$. (bottom) Corresponding 10-yr moving window elevation where temperature (red circles with red linear fit) and precipitation (blue circles with blue linear fit) $|r|=0.5$. MannKendall $p$ values and Theil-Sen slope estimates are also shown. 
streamflow gauge elevation. The precipitation correlations exhibit a stronger linear relationship with elevation for the four periods (mean $\left.r^{2}=0.60\right)$ than temperature (mean $\left.r^{2}=0.40\right)$. At low elevations $(<1500 \mathrm{~m})$, precipitation is weakly related to annual $Q_{\max }$ changes. Alternatively, at higher elevations $(>1500 \mathrm{~m})$, precipitation is directly related to annual $Q_{\max }$ changes. At low elevations, the correlation between temperature and annual $Q_{\max }$ changes is weaker $(r>-0.2)$. At high elevations, the relationship is inverse and the magnitude of the inverse relationship increases with elevation. Both the temperature and precipitation correlations are strongest $(|r|>0.5)$ at high elevations $(>2300 \mathrm{~m})$.

The bottom panels of Fig. 2 also show the temporal change of the elevation at which $25 \%$ of the variability in $Q_{\max }$ is explained by these climate variables with time. For temperature, the threshold elevation increases by 4.8 and $1.6 \mathrm{~m} \mathrm{yr}^{-1}$, respectively, for the two shorter periods (1985-2014 and 1975-2014) and decreases by 2.5 and $0.3 \mathrm{~m} \mathrm{yr}^{-1}$, respectively, for the two longer periods (1965-2014 and 1955-2014). The threshold elevation also increases for precipitation in three of the four periods by up to $3.4 \mathrm{~m} \mathrm{yr}^{-1}$ and decreases in the shortest period (1985-2014) by $0.1 \mathrm{~m} \mathrm{yr}^{-1}$. All elevation increases for precipitation are statistically significant using the standard Student's $t$ test $(p<0.05)$. None of the elevation changes for temperature were statistically significant.

The correlation coefficients between annual CT versus April-May temperature and precipitation are plotted as a function of streamflow gauge elevation for each of the four time periods in Fig. 3. The precipitation correlations exhibit a stronger linear relationship with elevation than temperature for the four periods (mean $r^{2}=0.73$ and 0.69 for precipitation and temperature, respectively). At low elevations $(<1500 \mathrm{~m})$, the correlations between precipitation and annual CT are weaker, whereas at high elevations $(>2300 \mathrm{~m})$, the correlations are direct, meaning that an increase in precipitation causes a delay in annual CT above $2300 \mathrm{~m}$. At low elevations $(<1500 \mathrm{~m})$, the correlations between temperature and annual $\mathrm{CT}$ are direct but generally weaker $(r<0.3)$. At high elevations $(>2300 \mathrm{~m})$, the correlations are inverse and much stronger $(r<-0.5)$. Similar to the correlations between climate and annual $Q_{\text {max }}$, the temperature and precipitation correlations with annual CT are strongest $(|r|>0.5)$ at high elevations $(>2300 \mathrm{~m})$.

The bottom panels of Fig. 3 also show the temporal change of the elevation at which $25 \%$ of the variability in CT is explained by these climate variables with time. For temperature, the threshold elevation increases in all four periods at a rate of $0.8-2.2 \mathrm{~m} \mathrm{yr}^{-1}$. The corresponding threshold elevation corresponding to the critical proportion of the variance explained by precipitation increases at a rate of $0.8-6.1 \mathrm{~m} \mathrm{yr}^{-1}$ for three of the four periods, and it decreases by $1.1 \mathrm{~m} \mathrm{yr}^{-1}$ for the 1975-2014 period. Two of the increases for temperature and two for precipitation are statistically significant $(p<0.05)$.

The elevation dependence of the correlation coefficients between March and April snow versus annual $Q_{\max }$, as well as April-May snow versus annual CT, is illustrated in Fig. 4. Both exhibit linear relationships with elevation $\left(r^{2}=0.68\right.$ and 0.64 , respectively). At high elevations $(>2300 \mathrm{~m})$ the correlations are strong and increase with elevation $(r>0.5)$, whereas below this elevation the correlations of snow with either $Q_{\max }$ or CT get progressively weaker. The elevation at which $25 \%$ of the variance in annual $Q_{\max }$ and annual CT is explained by interannual snow variability decreased over time, by 9.1 and $1.1 \mathrm{~m} \mathrm{yr}^{-1}$, respectively. The result is in contrast to the change in elevation dependence (increasing with time) associated with precipitation and temperature influences described above.

\section{Discussion}

The difference between temperature effects on streamflow at high versus low elevations shown in Figs. 2 and 3 indicates that warming has a strong influence on streamflow through changes in snowmelt. This is based on the finding that the April-May temperature correlations with streamflow are highest at elevations above $2300 \mathrm{~m}$, which coincides with areas where snowpack and snowmelt are appreciable in the CRB. At lower elevations, where the influence of snow accumulation and melt would have a smaller relative role in the subbasinscale hydrologic cycle and water budget, the same correlations were found to be much weaker.

According to existing literature, our finding of the inverse relationship between April and May temperature and streamflow CT from earlier snowmelt above $2300 \mathrm{~m}$ may be indicative of a negative feedback on the rate of ET. The advancement in CT due to earlier snowmelt indicates a simultaneous advancement of moisture availability on hillslopes and water in streams because less water is being stored in snowpack at higher elevations. However, this advancement in moisture availability comes at a time of year when available energy to generate ET is lower, thereby minimizing the effects that warming-induced increases in ET will have on streamflow (Barnett et al. 2005). A similar phenomenon was found to be responsible for the slowdown of snowmelt rates in a warmer climate (Musselman et al. 2017). 
a. $1985-2014$

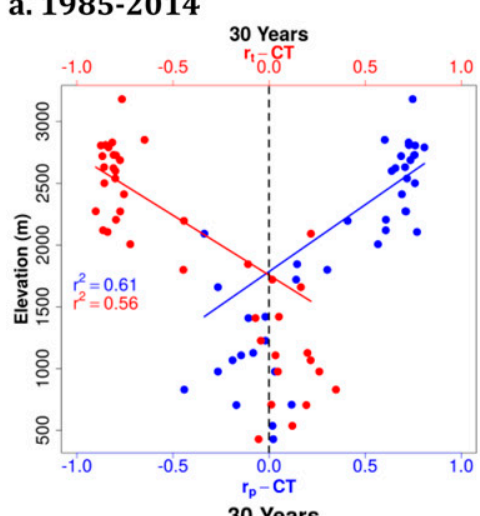

30 Years

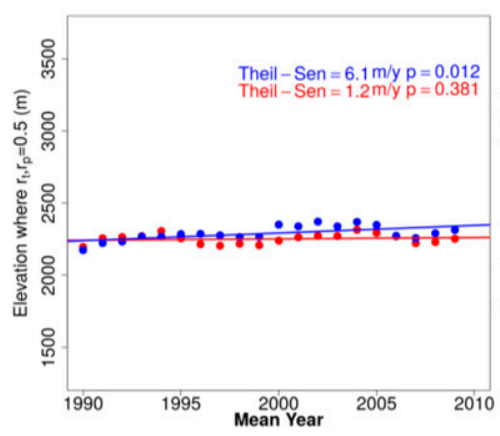

\section{d. 1955-2014}
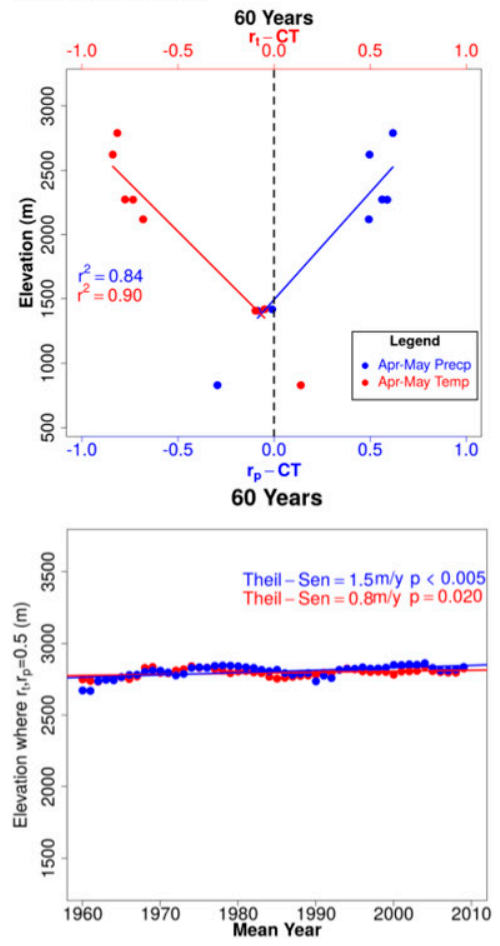

b. 1975-2014

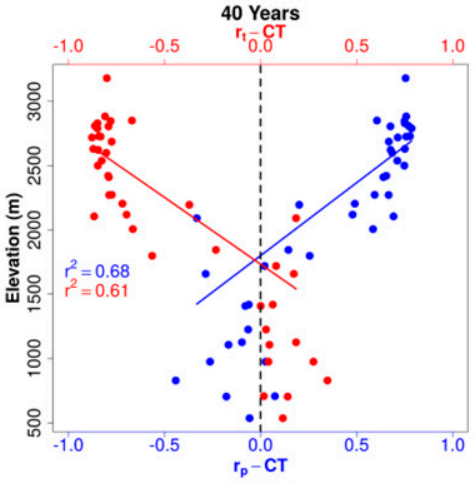

40 Years

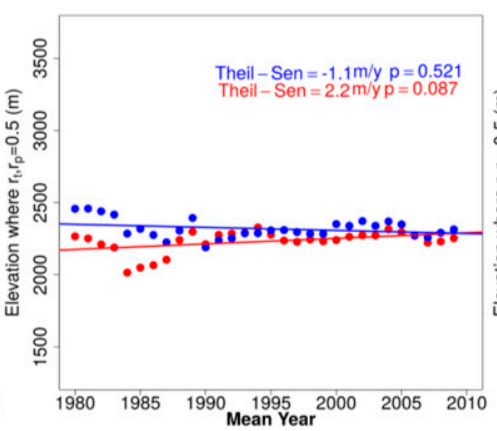

c. $1965-2014$
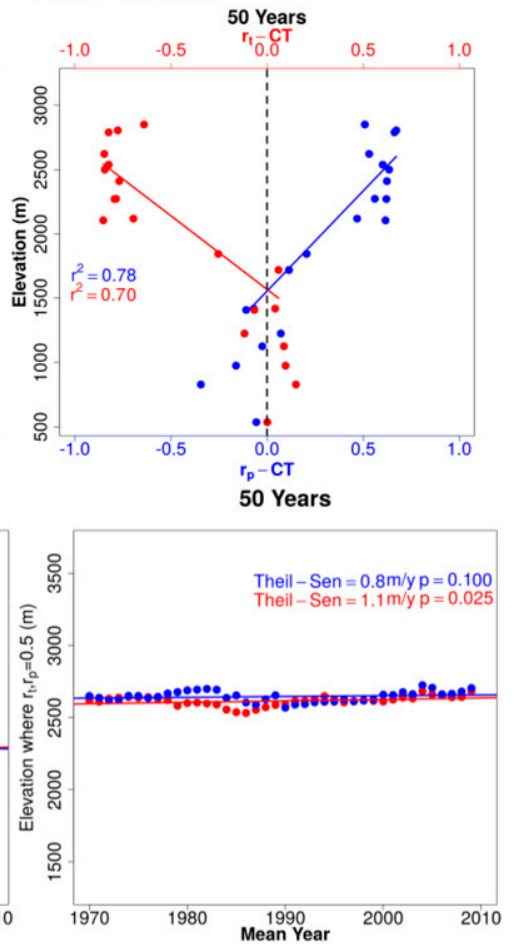

FIG. 3. (top) Pearson correlation coefficients between annual CT vs AprilMay precipitation (blue circles with blue linear fit) and vs April-May temperature (red circles with red linear fit) plotted against elevation for (a)-(d) each period. Linear fits were conducted only for stations above $1300 \mathrm{~m}$. (bottom) Corresponding 10-yr moving window elevation where temperature (red circles with red linear fit) and precipitation (blue circles with blue linear fit) $|r|=0.5$. Mann-Kendall $p$ values and Theil-Sen slope estimates are also shown. 

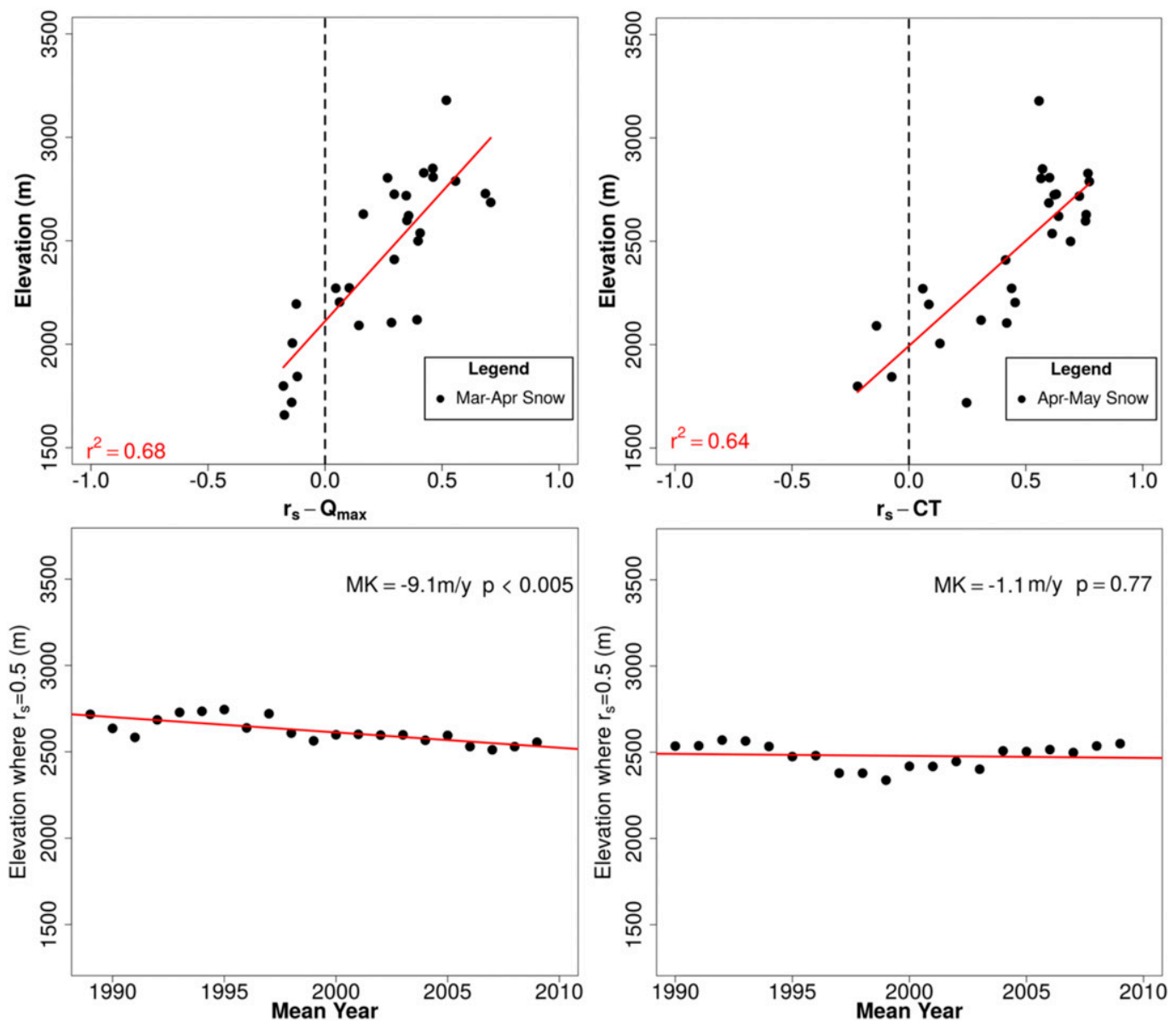

FIG. 4. Pearson correlation coefficients (black circles with red linear fit) (top left) between 1985-2014 annual $Q_{\max }$ and March-April snow and (top right) annual CT with April-May snow plotted against elevation. Linear fits were conducted only for stations above $1300 \mathrm{~m}$. Corresponding 10-yr moving window mean elevation where $r_{s}=0.5$ for (bottom left) $Q_{\max }$ and (bottom right) CT. Mann-Kendall $p$ values and Theil-Sen slope estimates are also shown.

The correlations between April and April-May precipitation and annual streamflow strengthened with increasing elevation for both annual $Q_{\max }$ and annual CT. At low elevations (below $1500 \mathrm{~m}$ ), however, the temperature during these months is warm enough to cause a greater fraction of precipitation to occur as rainfall within the CRB (Clow 2010; Kampf and Lefsky 2016). Thus, in the absence of substantial snow upgradient within a given catchment, higher precipitation at low elevations leads to a more instantaneous response in the annual hydrograph that may not be synchronized with snowmelt runoff (Kampf and Lefsky 2016). Streamflow at gauges within the southern part of the CRB, throughout much of Arizona, is likely to behave this way as the elevation is much lower and exists at lower latitudes relative to the rest of the CRB. More cold season rainfall increases the likelihood of earlier peak runoff and decreases the sharpness of the snowmelt runoff peak, thereby decreasing both $Q_{\max }$ and CT. Hence, these streamflow metrics are inversely related to both temperature and precipitation. We note that this scenario would not hold true for gauges located on rivers within the southern CRB where snow still accounts for a substantial portion of the annual water budget upstream (e.g., mainstem Colorado River). Given the extent of reservoir management and diversions above these locations within the CRB (Nilsson et al. 2005), we did not target such gauges for our analysis to avoid interference with the snowmelt signal in the annual hydrograph from water management.

At elevations above $2300 \mathrm{~m}$ within the CRB, most of the cold season precipitation falls as snow, resulting in a delayed CT response in the annual hydrograph. Because precipitation at higher elevations within the same catchment is likely to be greater due to orographic precipitation enhancement (Daly et al. 1994), the impact on the annual hydrograph from precipitation at higher elevations is stronger, resulting in a much stronger and 
positive correlation between precipitation and temperature and $Q_{\max }$ or CT. The effect that orographic precipitation enhancement has on streamflow serves to counteract the expected inverse correlation between temperature and precipitation with annual $Q_{\max }$ and annual CT at lower elevations within the same catchment, resulting in negligible correlations (weakly positive or negative), as shown in our results.

Some of the relationships in the top panels of Figs. 2 and 3 are not fully linear and show some degree of clustering for the stations located at elevations above $2500 \mathrm{~m}$. However, the use of linear correlation analysis still provides a useful initial strategy for parameterizing potential hydroclimatic relationships and elevation in models. Moreover, the similarity in the linear fits among the 30-, 40-, 50-, and 60-yr periods both in terms of slope magnitude and direction as illustrated in the plots further suggests that the linearity of hydroclimatic relationships above $1300 \mathrm{~m}$ is a robust result.

Warming-induced changes in streamflow are shown in the bottom panels of both Figs. 2 and 3, revealing elevational shifts over time in the correlations between temperature, precipitation, and annual streamflow metrics. The elevation where $25 \%$ of the variability in annual $Q_{\max }$ and annual CT can be explained by temperature and precipitation is increasing in six of these eight plots. This result makes sense given the warminginduced declines in snow that have already been noted within the CRB (Mote 2006; Knowles et al. 2006; McCabe et al. 2007). Throughout western North America, these declines have been particularly acute in regions where the cold season temperatures are close to freezing - that is, within elevations close to the historical seasonal rainto-snow line (Adam et al. 2009; Clow 2010). Such trends are expected to continue as a component of future warming (Klos et al. 2014).

Trend analysis (Figs. 1, 2) illustrates that warming is also shifting the elevation of fundamental hydroclimatic relationships between climate and streamflow. However, we note that the impact of such trends on streamflow timing in the CRB does not appear to be as strong, as decreasing trends were observed in the threshold elevation where $25 \%$ of the annual CT can be explained by temperature in the two longer-period plots of 50 and 60 years. Moreover, none of the increasing or decreasing trends in elevation for temperature were statistically significant $(p<0.05)$. Further testing is necessary to determine if the increasing trends in elevation of hydroclimatic relationships are substantial enough to cause an overall change in the sensitivity of the watershed to warming, making it more resilient over time. We did not explicitly test for this in our study.
The more robust increases that were noted in the threshold elevation for the relationship between precipitation and annual CT indicate that the quantity of precipitation plays a larger role in historical streamflow timing than temperature or precipitation phase. This is supported by the overall weaker influence of anthropogenic warming on changes in $\mathrm{CT}$ that were observed for the upper CRB compared to the Columbia, Sacramento, and San Joaquin River basins (Hidalgo et al. 2009).

The bottom panels of Fig. 4 indicate that the relationship with respect to snow is opposite to that described above-that is, the threshold elevation decreases with time. Increases in snowfall over the study period could potentially offset the impact that warming has on streamflow changes caused by snowmelt shifts, which was already shown to be the case in simulations using the Variable Infiltration Capacity model for the CRB from 1947 to 2003 (Hamlet et al. 2005) as well as from observations (Knowles et al. 2006). Although this explanation appears to contradict the previous paragraph, snowfall declines for the historical seasonal rainto-snow lines can still occur while overall mountain snowfall volume integrated across all elevations within a catchment increases. Such a scenario would prevent an increase in the threshold elevation where snow explains $25 \%$ of the variability in annual $Q_{\max }$ and annual $\mathrm{CT}$, as was found in our study.

Accuracy in snow estimates from Daymet may also be contributing to the decrease in the snow threshold elevation. Geographical variability of snow is notoriously difficult to reproduce, particularly in mountainous areas (Rittger et al. 2016). Furthermore, had 60-yr snow records been available for comparison to streamflow changes, as was the case for the precipitation and temperature records, this threshold elevation for snow might have also been shown to increase over some periods. According to probabilistic model simulations, the snow line elevation is expected to continue to increase (Klos et al. 2014), motivating improvements in ground-based and remotely sensed observations of snow (e.g., Painter et al. 2016) and maintaining and expanding in situ observation networks such as the Snowpack Telemetry (SNOTEL) stations maintained by the U.S. Natural Resources Conservation Service. Better direct estimates of snow derived from these products and measurements could help to constrain elevation-dependent changes in the relationship with streamflow, as well as the rate at which changes in these relationships are occurring.

At sufficiently high elevations, much larger temperature increases than observed historically are required to cause premature snowmelt to have a noticeable impact 
on annual $Q_{\max }$ or CT (Clow 2010; Kapnick and Hall 2012). If present in our analysis, the signature of this shift in the relationship between temperature and streamflow would be expressed as a decrease over time in the magnitude of the anticorrelations between temperature and streamflow at higher elevations. Such a scenario was reported for the relationship between snowpack and temperature as well as snowpack and precipitation with the discovery of an elevation threshold above which precipitation had a greater influence on snowpack variability and below which temperature had greater influence (Morán-Tejeda et al. 2013; Sospedra-Alfonso et al. 2015; Scalzitti et al. 2016). As this threshold was not detected in this study (Figs. 1, 2), we conclude that availability of higher elevation $(>3000 \mathrm{~m})$ natural streamflow observations within the CRB was insufficient to identify where this transition occurs. This is an important point for scientists and water managers who rely on the GAGES-II dataset for calculating changes in streamflow. Without explicit field observations above $3000 \mathrm{~m}$ designed to examine how these changes are occurring, this transition can only be revealed through simulations of coupled climate and land surface hydrology models, in conjunction with long-term remotely sensed observational datasets at high elevations for process development, testing, and validation.

Based on Figs. 1 and 2, temperature and precipitation are approximately equally correlated with $Q_{\max }$ and $\mathrm{CT}$ at elevations above $2300 \mathrm{~m}$. We interpret this result to be due to the strong influence of snow above this elevation in the CRB. Previous studies have also stated that snow becomes a significant fraction of total winter and spring precipitation above $2300 \mathrm{~m}$ (Clow 2010; Kampf and Lefsky 2016). Changes in the relationship between the normalized difference vegetation index (NDVI) and precipitation only became important at a similar elevation threshold due to the emergence of substantial annual snowpack at these elevations (Herrmann et al. 2016). Such observations and findings are consistent with our study, where snow emerges as being strongly correlated with annual $Q_{\max }$ and annual CT (Fig. 3) at the same elevation threshold. The observations that both temperature and precipitation emerge as having a strong influence on streamflow above $2300 \mathrm{~m}$, and that temperature and precipitation correlations with streamflow increase at approximately the same rate above this elevation, further reveals that changing snow and snowmelt patterns due to warming are the specific drivers for changes in streamflow timing and high flow extremes within the CRB.

Our discovery-driven data analysis provides guidance for future research based on process simulation

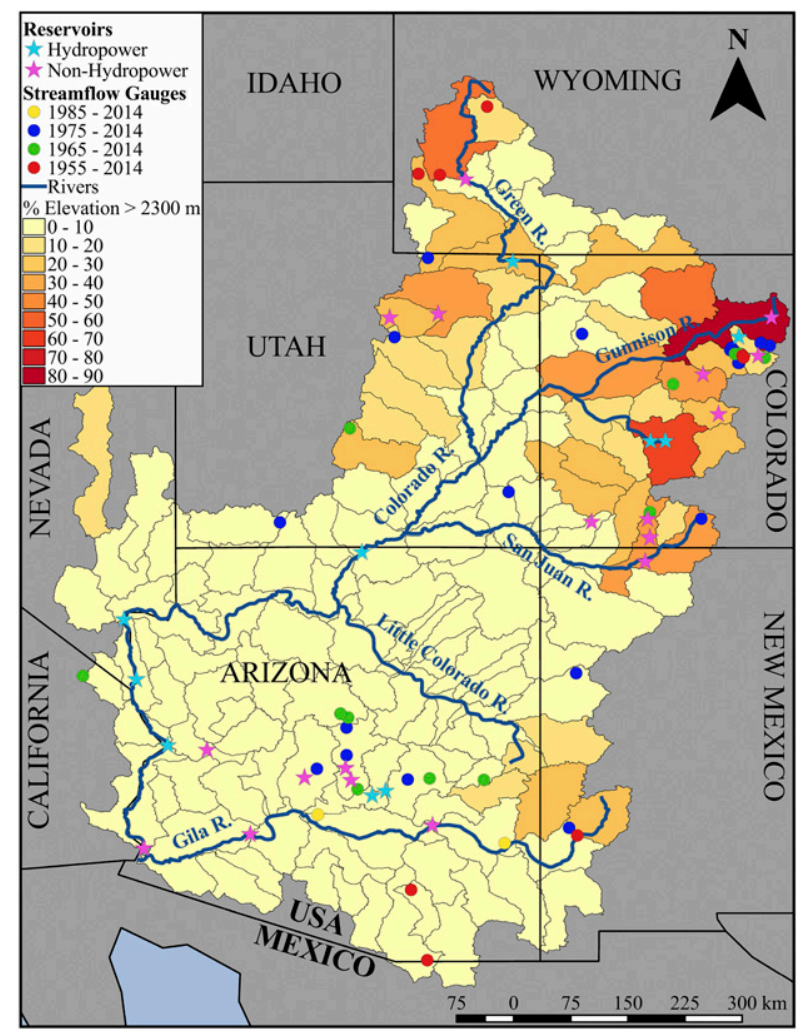

FIG. 5. Percentage of the surface area within each HUC-8 watershed within the CRB where elevation $>2300 \mathrm{~m}$. Darker colors indicate higher-elevation watersheds, where annual $Q_{\max }$ and annual CT undergo the greatest change from warming. Locations of major reservoirs (hydropower and nonhydropower) also shown for reference.

modeling of the impacts of climatic variability and change on water resources in the CRB. Our aim was to establish a historical baseline of these relationships using observational datasets. Subsequent simulations using physically based (mechanistic) models could then be used to assess how well the observed relationships are captured in the current generation of models and to make projections of how these hydroclimatic mechanisms might change in the future.

Given the elevation dependence of the streamflow response to temperature and precipitation revealed by our results, an additional analysis was conducted to determine the relative vulnerability of streamflow within different watersheds to future change (Fig. 5). Watersheds from the U.S. Geological Survey 8-digit hydrologic unit code (HUC-8) system are classified according to the percent watershed area lying above the critical elevation of $2300 \mathrm{~m}$, given the stronger relationship between climate and streamflow change we observe above this elevation in our results. The most vulnerable watersheds were heuristically defined as those with greater 
than $10 \%$ surface area above this threshold elevation. With a few notable exceptions, these watersheds are clustered in headwater regions of the upper CRB. Specifically, affected areas include the headwater basins of the mainstem Colorado River and the San Juan River of western Colorado, as well as the Green River of southern Wyoming and eastern Utah. We acknowledge that a more detailed site-specific analysis is required to account for all factors that are likely to contribute to streamflow changes within these watersheds. For example, process models could be used to better constrain the hydroclimatic relationships at upper elevations and evaluate changes in the future. Moreover, we have not explicitly accounted for dust-on-snow effects, which can compound and even surpass the effect that temperature alone has on advancing snowmelt in this region (Painter et al. 2018). Figure 5 provides a firstorder assessment of where the largest changes in streamflow extremes and timing are expected to occur based on changes already observed within the CRB.

\section{Conclusions}

We empirically quantified key climatic drivers of annual $Q_{\max }$ and annual CT, the dependence of these hydroclimatic relationships with elevation, and linear trend rates in the elevation dependence relationships over the past 60 years in the CRB. Our results indicate a threshold elevation of $2300 \mathrm{~m}$, above which correlations between temperature, precipitation, and streamflow were generally strong $\left(\left|r^{2}\right|>0.50\right)$. Given that this elevation threshold aligns with the locations where snow plays an important role in streamflow, we conclude that changes in snow and snowmelt from warming are largely driving the variability in annual $Q_{\max }$ and annual CT. The mean elevations at which $Q_{\max }$ and CT exhibit a strong sensitivity to April-May temperature variability are increasing by up to 4.8 and $2.2 \mathrm{~m} \mathrm{yr}^{-1}$, respectively, suggesting that warming-induced changes in snowmelt or phase shifts in snow are changing the relationship between climate and streamflow within the CRB.

Based on our findings and because warming trends are expected to continue, more severe changes in streamflow are anticipated in the future, particularly for CRB watersheds above the critical elevation threshold of $2300 \mathrm{~m}$ or those immediately downgradient. These regions are highlighted for the CRB in a vulnerability map that depicts watersheds where water resources are likely to be most vulnerable to changes in annual $Q_{\max }$ and annual CT. Such an analysis is useful for targeted management improvements to address energy, water, and food supply concerns. Simulating these changes within hydrology and climate models coupled to energy, water, and food supply or flood models will be necessary to pinpoint how these resources and critical infrastructure will be affected and to mitigate potentially associated economic or environmental losses using new river management and planning protocols.

Acknowledgments. This project was supported by the Los Alamos National Laboratory's Laboratory Directed Research and Development (LDRD) program under the Critical Watersheds project (20150397DR). Streamflow gauge data for this research were obtained from the U.S. Geological Survey and is publicly available (www.water.usgs.gov, accessed 6 March 2017). Precipitation and temperature data for this research were obtained from the Parameter-Elevation Regressions on Independent Slopes Model (PRISM) at 4-km resolution and is publicly available (http://prism. oregonstate.edu/, accessed 8 February 2017). Snow water equivalent data were obtained from publicly available Daymet Version 3 data gridded at 1-km resolution (https://daymet.ornl.gov/, accessed 5 September 2017).

\section{REFERENCES}

Adam, J. C., A. F. Hamlet, and D. P. Lettenmaier, 2009: Implications of global climate change for snowmelt hydrology in the twenty-first century. Hydrol. Processes, 23, 962-972, https:// doi.org/10.1002/hyp.7201.

Barnett, T. P., J. C. Adam, and D. P. Lettenmaier, 2005: Potential impacts of a warming climate on water availability in snowdominated regions. Nature, 438, 303-309, https://doi.org/ 10.1038/nature04141.

— , and Coauthors, 2008: Human-induced changes in the hydrology of the western United States. Science, 319, 1080-1083, https://doi.org/10.1126/science.1152538

Bartos, M. D., and M. V. Chester, 2015: Impacts of climate change on electric power supply in the western United States. Nat. Climate Change, 5, 748-752, https://doi.org/ 10.1038/nclimate2648

Bennett, K. E., T. Bohn, K. C. Solander, N. G. McDowell, C. Xu, E. R. Vivoni, and R. S. Middleton, 2018: Climate change and climate-driven disturbances in the San Juan River sub-basin of the Colorado River. Hydrol. Earth Syst. Sci., 22, 709-725, https://doi.org/10.5194/hess-22-709-2018.

Berghuijs, W. R., R. A. Woods, and M. Hrachowitz, 2014: A precipitation shift from snow towards rain leads to a decrease in streamflow. Nat. Climate Change, 4, 583-586, https://doi.org/ 10.1038/nclimate2246.

Bryant, A. C., T. H. Painter, J. S. Deems, and S. M. Bender, 2013: Impact of dust radiative forcing in snow on accuracy of operational runoff prediction in the Upper Colorado River Basin. Geophys. Res. Lett., 40, 3945-3949, https://doi.org/10.1002/ grl.50773.

Cayan, D. R., L. G. Riddle, and E. Aguado, 1993: The influence of precipitation and temperature on seasonal streamflow in California. Water Resour. Res., 29, 1127-1140, https://doi.org/ 10.1029/92WR02802. 
Clow, D. W., 2010: Changes in the timing of snowmelt and streamflow in Colorado: A response to recent warming. J. Climate, 23, 2293-2306, https://doi.org/10.1175/2009JCLI2951.1.

Daly, C., R. P. Neilson, and D. L. Phillips, 1994: A statistical-topographic model for mapping climatological precipitation over mountainous terrain. J. Appl. Meteor., 33, 140-158, https://doi.org/ 10.1175/1520-0450(1994)033<0140:ASTMFM>2.0.CO;2.

_- M. Halbleib, J. I. Smith, W. P. Gibson, M. K. Doggett, G. H. Taylor, J. Curtis, and P. P. Pasteris, 2008: Physiographically sensitive mapping of climatological temperature and precipitation across the conterminous United States. Int. J. Climatol., 28, 2031-2064, https://doi.org/10.1002/ joc. 1688.

Das, T., D. W. Pierce, D. R. Cayan, J. A. Vano, and D. P. Lettenmaier, 2011: The importance of warm season warming to western U.S. streamflow changes. Geophys. Res. Lett., 38, L23403, https://doi.org/10.1029/2011GL049660.

Dunne, T., and L. B. Leopold, 1978: Water in Environmental Planning. W. H. Freeman, 818 pp.

Falcone, J. A., D. M. Carlisle, D. M. Wolock, and M. R. Meador, 2010: GAGES: A stream gage database for evaluating natural and altered flow conditions in the conterminous United States. Ecology, 91, 621, https://doi.org/10.1890/09-0889.1.

Feng, S., and Q. Hu, 2007: Changes in winter snowfall/precipitation ratio in the contiguous United States. J. Geophys. Res., 112, D15109, https://doi.org/10.1029/2007JD008397.

Ficklin, D. L., I. T. Stewart, and E. P. Maurer, 2013: Climate change impacts on streamflow and subbasin-scale hydrology in the Upper Colorado River Basin. PLOS ONE, 8, e71297, https:// doi.org/10.1371/journal.pone.0071297.

Foster, L. M., and Coauthors, 2016: Energy budget increases reduce mean streamflow more than snow-rain transitions: Using integrated modeling to isolate impacts on Rocky Mountain hydrology. Environ. Res. Lett., 11, 044015, https://doi.org/ 10.1088/1748-9326/11/4/044015.

Fritze, H., I. T. Stewart, and E. Pebesma, 2011: Shifts in western North American snowmelt runoff regimes for the recent warm decades. J. Hydrometeor., 12, 989-1006, https://doi.org/ 10.1175/2011JHM1360.1.

Gao, Y., R. M. Vogel, C. N. Kroll, N. L. Poff, and J. D. Olden, 2009: Development of representative indicators of hydrologic alteration. J. Hydrol., 374, 136-147, https://doi.org/10.1016/ j.jhydrol.2009.06.009.

Groisman, P. Y., R. W. Knight, and T. R. Karl, 2001: Heavy precipitation and high streamflow in the contiguous United States: Trends in the twentieth century. Bull. Amer. Meteor. Soc., 82, 219-246, https://doi.org/10.1175/1520-0477(2001)082<0219: HPAHSI $>2.3$.CO;2.

Hamlet, A. F., P. W. Mote, M. P. Clary, and D. P. Lettenmaier, 2005: Temperature and precipitation variability on snowpack trends in the western United States. J. Climate, 18, 4545-4561, https://doi.org/10.1175/JCLI3538.1.

,-- M. P. Clark, and D. P. Lettenmaier, 2007: Twentiethcentury trends in runoff, evapotranspiration, and soil moisture in the western United States. J. Climate, 20, 1468-1486, https:// doi.org/10.1175/JCLI4051.1.

Herrmann, S. M., K. Didan, A. Barreto-Munoz, and M. Crimmins, 2016: Divergent responses of vegetation productivity in Southwestern US ecosystems to dry and wet years at different elevations. Environ. Res. Lett., 11, 124005, https://doi.org/ 10.1088/1748-9326/11/12/124005.

Hidalgo, H. G., and Coauthors, 2009: Detection and attribution of streamflow timing changes to climate change in the western
United States. J. Climate, 22, 3838-3855, https://doi.org/ 10.1175/2009JCLI2470.1.

Hodgkins, G. A., R. W. Dudley, and L. F. Schalk, 2012: Relations between winter climatic variables and April streamflows in New England and implications for summer streamflows. USGS Scientific Investigations Rep. 2012-5092, 19 pp., https:// pubs.usgs.gov/sir/2012/5092/pdf/sir2012-5092_report_508.pdf.

Kampf, S. K., and M. A. Lefsky, 2016: Transition of dominant peak flow source from snowmelt to rainfall along the Colorado Front Range: Historical patterns, trends, and lessons from the 2013 Colorado Front Range floods. Water Resour. Res., 52, 407-422, https://doi.org/10.1002/2015WR017784.

Kapnick, S., and A. Hall, 2012: Causes of recent changes in western North American snowpack. Climate Dyn., 38, 1885-1899, https://doi.org/10.1007/s00382-011-1089-y.

Klos, P. Z., T. E. Link, and J. T. Abatzoglou, 2014: Extent of the rain-snow transition zone in the western U.S. under historic and projected climate. Geophys. Res. Lett., 41, 4560-4568, https://doi.org/10.1002/2014GL060500.

Knowles, N., M. D. Dettinger, and D. R. Cayan, 2006: Trends in snowfall versus rainfall in the western United States. J. Climate, 19, 4545-4559, https://doi.org/10.1175/JCLI3850.1.

Kumar, M., R. Wang, and T. E. Link, 2012: Effects of more extreme precipitation regimes on maximum seasonal snow water equivalent. Geophys. Res. Lett., 39, L20504, https:/doi.org/ 10.1029/2012GL052972.

Lehner, F., A. W. Wood, D. Llewellyn, D. B. Blatchford, A. G. Goodbody, and F. Pappenberger, 2017a: Mitigating the impacts of climate nonstationarity on seasonal streamflow predictability in the U.S. Southwest. Geophys. Res. Lett., 44, 12 208-12 217, https://doi.org/10.1002/2017GL076043.

, E. R. Wahl, A. W. Wood, D. B. Blatchford, and D. Llewellyn, 2017b: Assessing recent declines in Upper Rio Grande runoff efficiency from a paleoclimate perspective. Geophys. Res. Lett., 44, 4124-4133, https://doi.org/ 10.1002/2017GL073253.

Luce, C. H., V. Lopez-Burgos, and Z. Holden, 2014: Sensitivity of snowpack storage to precipitation and temperature using spatial and temporal analog models. Water Resour. Res., 50, 9447-9462, https://doi.org/10.1002/2013WR014844.

MacDonald, G. M., 2010: Water, climate change, and sustainability in the southwest. Proc. Natl. Acad. Sci. USA, 107, $21256-$ 21 262, https://doi.org/10.1073/pnas.0909651107.

Mankin, J. S., and N. S. Diffenbaugh, 2015: Influence of temperature and precipitation variability on near-term snow trends. Climate Dyn., 45, 1099-1116, https://doi.org/10.1007/ s00382-014-2357-4.

McCabe, G. J., and M. P. Clark, 2005: Trends and variability in snowmelt runoff in the western United States. J. Hydrometeor., 6, 476-482, https://doi.org/10.1175/JHM428.1.

$\longrightarrow$ - $\longrightarrow$ and L. E. Hay, 2007: Rain-on-snow events in the western United States. Bull. Amer. Meteor. Soc., 88, 319-328, https://doi.org/10.1175/BAMS-88-3-319.

, D. M. Wolock, G. T. Pederson, C. A. Woodhouse, and S. McAfee, 2017: Evidence that recent warming is reducing upper Colorado River flows. Earth Interact., 21, https:// doi.org/10.1175/EI-D-17-0007.1.

Miller, W. P., and T. C. Piechota, 2008: Regional analysis of trend and step changes observed in hydroclimatic variables around the Colorado River Basin. J. Hydrometeor., 9, 1020-1034, https://doi.org/10.1175/2008JHM988.1.

Morán-Tejeda, E., J. I. López-Moreno, and M. Beniston, 2013: The changing roles of temperature and precipitation on snowpack 
variability in Switzerland as a function of altitude. Geophys. Res. Lett., 40, 2131-2136, https://doi.org/10.1002/grl.50463.

Mote, P. W., 2006: Climate-driven variability and trends in mountain snowpack in Western North America. J. Climate, 19, 6209-6220, https://doi.org/10.1175/JCLI3971.1.

Musselman, K. N., M. P. Clark, C. Liu, K. Ikeda, and R. Rasmussen, 2017: Slower snowmelt in a warmer world. Nat. Climate Change, 7, 214-219, https://doi.org/10.1038/nclimate3225.

Nilsson, C., C. Reidy, M. Dynesius, and C. Revenga, 2005: Fragmentation and flow regulation of the world's large river systems. Science, 308, 405-408, https://doi.org/10.1126/science.1107887.

Nowak, K., M. Hoerling, B. Rajagopalan, and E. Zagona, 2012: Colorado River Basin hydroclimatic variability. J. Climate, 25, 4389-4403, https://doi.org/10.1175/JCLI-D-11-00406.1.

Painter, T. H., J. S. Deems, J. Belnap, A. F. Hamlet, C. C. Landry, and B. Udall, 2010: Response of Colorado River runoff to dust radiative forcing in snow. Proc. Natl. Acad. Sci. USA, 107, 17125-17 130, https://doi.org/10.1073/pnas.0913139107.

_ - and Coauthors, 2016: The Airborne Snow Observatory: Fusion of scanning lidar, imaging spectrometer, and physicallybased modeling for mapping snow water equivalent and snow albedo. Remote Sens. Environ., 184, 139-152, https://doi.org/ 10.1016/j.rse.2016.06.018.

— S. M. Skiles, J. S. Deems, W. T. Brandt, and J. Dozier, 2018: Variation in rising limb of Colorado River snowmelt runoff hydrograph controlled by dust radiative forcing in snow. Geophys. Res. Lett., 45, 797-808, https://doi.org/10.1002/ 2017GL075826.

Pederson, G. T., J. L. Betancourt, and G. J. McCabe, 2013: Regional patterns and proximal causes of the recent snowpack decline in the Rocky Mountains, U.S. Geophys. Res. Lett., 40, 1811-1816, https://doi.org/10.1002/grl.50424.

Regonda, S. K., B. Rajagopalan, M. Clark, and J. Pitlick, 2005: Seasonal cycle shifts in hydroclimatology over the western United States. J. Climate, 18, 372-384, https://doi.org/10.1175/ JCLI-3272.1.

Rittger, K., E. H. Bair, A. Kahl, and J. Dozier, 2016: Spatial estimates of snow water equivalent from reconstruction. Adv. Water Resour., 94, 345-363, https://doi.org/10.1016/ j.advwatres.2016.05.015.

Sabo, J. L., and Coauthors, 2010: Reclaiming freshwater sustainability in the Cadillac Desert. Proc. Natl. Acad. Sci. USA, 107, 21 263-21 270, https://doi.org/10.1073/pnas.1009734108.

Scalzitti, J., C. Strong, and A. Kochanski, 2016: Climate change impact on the roles of temperature and precipitation in western U.S. snowpack variability. Geophys. Res. Lett., $\mathbf{4 3}$ 5361-5369, https://doi.org/10.1002/2016GL068798.

Skiles, S. M. K., T. H. Painter, J. Belnap, L. Holland, R. L. Reynolds, H. L. Goldstein, and J. Lin, 2015: Regional variability in dust-on-snow processes and impacts in the Upper Colorado River Basin. Hydrol. Processes, 29, 5397-5413, https://doi.org/10.1002/hyp.10569.

Solander, K. C., J. T. Reager, Y. Wada, J. S. Famiglietti, and R. S. Middleton, 2017a: GRACE satellite observations reveal the severity of recent water over-consumption in the United States. Sci. Rep., 7, 8723, https://doi.org/10.1038/ s41598-017-07450-y.

_ K. E. Bennett, and R. S. Middleton, 2017b: Shifts in historical streamflow extremes in the Colorado River Basin. J. Hydrol: Reg. Stud., 12, 363-377, https://doi.org/10.1016/ j.ejrh.2017.05.004.

Sospedra-Alfonso, R., J. R. Melton, and W. J. Merryfield, 2015: Effects of temperature and precipitation on snowpack variability in the Central Rocky Mountains as a function of elevation. Geophys. Res. Lett., 42, 4429-4438, https://doi.org/ 10.1002/2015GL063898.

Thornton, P. E., M. M. Thornton, B. W. Mayer, Y. Wei, R. Devarakonda, R. S. Vose, and R. B. Cook, 2017. Daymet: Daily Surface Weather data on a 1-km grid for North America, version 3. ORNL DAAC, accessed 1 September 2017, https:// doi.org/10.3334/ORNLDAAC/1328.

Tsonis, A. A., K. L. Swanson, and P. J. Roebber, 2006: What do networks have to do with climate? Bull. Amer. Meteor. Soc., 87, 585-595, https://doi.org/10.1175/BAMS-87-5-585.

Udall, B., and J. Overpeck, 2017: The twenty-first century Colorado River hot drought and implications for the future. Water Resour. Res., 53, 2404-2418, https://doi.org/10.1002/2016WR019638.

Vano, J. A., and Coauthors, 2014: Understanding uncertainties in future Colorado Streamflow. Bull. Amer. Meteor. Soc., 95, 59-78, https://doi.org/10.1175/BAMS-D-12-00228.1.

_ B. Bijssen, and D. P. Lettenmaier, 2015: Seasonal hydrologic responses to climate change. Water Resour. Res., 51, 19591976, https://doi.org/10.1002/2014WR015909.

Witze, A., 2014: Water returns to arid Colorado River delta: USMexico agreement paves the way for a rare environmental test. Nature, 507, 286-287, https://doi.org/10.1038/507286a.

Woodhouse, C. A., G. T. Pederson, K. Morino, S. A. McAfee, and G. J. McCabe, 2016: Increasing influence of air temperature on upper Colorado River streamflow. Geophys. Res. Lett., 43, 2174-2181, https://doi.org/10.1002/2015GL067613. 